Zeszyty Naukowe Szkoły Głównej Gospodarstwa Wiejskiego w Warszawie

Problemy Rolnictwa Światowego tom 18 (XXXIII), zeszyt 1, 2018: 319-330

DOI: $10.22630 /$ PRS.2018.18.1.29

Wioletta Wróblewska $^{1}$, Lukasz Kopiński $^{2}$, Dariusz Paszko ${ }^{3}$, Joanna Pawlak $^{4}$

Uniwersytet Przyrodniczy w Lublinie

\title{
Unijny eksport i import roślin ozdobnych - zmiany w ujęciu rodzajowym i geograficznym
}

\section{EU Export and Import of Ornamental Plants - Changes in Generic and Geographical Approach}

\begin{abstract}
Synopsis. Celem artykułu była analiza zmian wartości unijnego handlu zagranicznego roślinami ozdobnymi w 1999 i 2014 roku w ujęciu rodzajowym i geograficznym. Uwzględniono wymianę handlową wewnątrzunijną, a także UE z krajami europejskimi spoza struktur Wspólnoty oraz Afryką, Bliskim Wschodem, Ameryką Płn., Ameryką Łacińską i pozostałymi regionami świata. Analizami objęto eksport i import roślin ozdobnych ogółem oraz siedmiu grup produktów kwiaciarskich. Analizowano saldo, poziom i dynamikę zmian handlu unijnego poszczególnymi grupami roślin ozdobnych z uwzględnieniem struktury geograficznej wymiany handlowej. Posłużono się indeksami o podstawie stałej oraz wykorzystano wskaźniki procentowe. Handel zagraniczny roślinami ozdobnymi UE charakteryzuje zasada bliskości geograficznej. Głównym dostawcą roślin ozdobnych w UE pozostaje Holandia, a głównym odbiorcą roślin ozdobnych z UE, ale o malejącym znaczeniu, były Niemcy. W handlu zagranicznym UE z innymi regionami świata wzrastała rola Afryki, jako dostawcy głównie kwiatów ciętych i sadzonek, malała rola Ameryki Płn. i Łacińskiej jako dostawców głównie zieleni ciętej. Znaczącymi odbiorcami cebul kwiatowych była Ameryka Płn. i Azja.
\end{abstract}

Słowa kluczowe: handel zagraniczny, export, import, rośliny ozdobne, Unia Europejska, świat

\begin{abstract}
The aim of the article was to analyze the changes in the value of EU foreign trade in ornamental plants in 1999 and 2014 in generic and geographical approach. Intra-EU trade, and the EU with European countries outside the Community, and Africa, the Middle East, North America, Latin America, and other regions of the world have been taken into account. The analysis covered the export and import of ornamental plants in total and seven groups of floricultural products. The balance, level and dynamics of changes of individual groups of ornamental plants in EU trade were analysed by taking into account the geographical structure of trade. The fixed base index and percentages were used. The foreign trade in ornamental plants of the EU is characterized by the principle of geographical proximity. The main supplier of decorative plants in the EU remains The Netherlands, and the main recipient of ornamental plants from the EU, but of decreasing importance, was Germany. In the EU's foreign trade with other regions of the world, the role of Africa grew as a supplier of mainly cut flowers and seedlings, it diminished the role of North and Latin America as suppliers of mainly cut greenery. Significant recipients of flower bulbs were North America and Asia.
\end{abstract}

Key words: foreigner trade, export, import, ornamental plants, European Union, World

JEL Classification: F14, Q17

\footnotetext{
${ }^{1}$ dr inż., Katedra Zarządzania i Marketingu UP w Lublinie, ul. B. Dobrzańskiego 37, 20-262 Lublin, e-mail: wioletta.wroblewska@up.lublin.pl

${ }^{2}$ mgr inż., Katedra Zarządzania i Marketingu UP w Lublinie, ul. B. Dobrzańskiego 37, $20-262$ Lublin, e-mail: lukasz.kopinski@up.lublin.pl

${ }^{3}$ dr inż., Katedra Zarządzania i Marketingu UP w Lublinie, ul. B. Dobrzańskiego 37, 20-262 Lublin, e-mail: dariusz.paszko@up.lublin.pl

${ }^{4}$ dr inż., Katedra Zarządzania i Marketingu UP w Lublinie, ul. B. Dobrzańskiego 37, 20-262 Lublin, e-mail: joanna.pawlak@up.lublin.pl
} 


\section{Wstęp}

Jak podaje Misala (2011) handel zagraniczny, a głównie eksport, jest „silnikiem”, który napędza rozwój gospodarki. Dlatego większości krajów coraz bardziej otwiera się na otoczenie międzynarodowe (Jabłońska i in., 2015). Efektem eksportu, jako czynnika kształtującego popyt jest uelastycznienie i rozszerzanie rynków zbytu, czyli sprzedaż większej liczbie uczestników globalnego rynku. Szczególnie w przypadku produktów, w stosunku do których występuje sytuacja niedoboru lub nasycenia popytu wewnętrznego, a takimi często są rośliny ozdobne, popyt na rynkach zagranicznych jest bardziej istotny niż na rynkach rodzimych i staje się bodźcem do zwiększania produkcji. Natomiast import, zwiększa konkurencję, co jest postrzegane negatywnie na poziomie producentów, jednak z punktu widzenia makroekonomicznego, m.in. przyczynia się do zwiększania asortymentu, wprowadzania postępu, obniżania kosztów (Jabłońska, 1999). Swobodny przepływ towarów jest jednym $\mathrm{z}$ największych sukcesów integracji gospodarczej Europy (Warunki..., 2012). Światowy sektor kwiaciarski charakteryzuje się wzrostem areału upraw, który przebiega z różną dynamiką w poszczególnych regionach świata (Jabłońska, 2008). Przy spowolnionym wzroście produkcji w krajach rozwiniętych (Jabłońska, 2007), równolegle rozwijana jest produkcja w krajach nie będących wcześniej producentami roślin ozdobnych, położonych we wschodniej i południowej Afryce (Goldfain, 2006; Gray, 2008). Europa, w tym UE jest drugim, po Azji, największym na świecie producentem kwiatów ciętych i doniczkowych (Jabłońska, 2007). Rozwojowi kwiaciarstwa w poszczególnych regionach świata towarzyszy jednocześnie wzrost międzynarodowej wymiany handlowej (Jabłońska, 2007; Marosz http://www.inhort.pl). W latach 1995-2010 unijny eksport i import roślin ozdobnych wzrósł odpowiednio 1,8 i 2,1- krotnie (Jabłońska i in., 2013).

Celem artykułu była analiza zmian wartości unijnego handlu zagranicznego roślinami ozdobnymi w ujęciu rodzajowym i geograficznym. Choć podstawę unijnych obrotów roślinami ozdobnymi stanowią obroty wewnątrzunijne (Wróblewska, 2010; Jabłońska i in., 2013), interesującym wydaje się poznanie kierunków handlu poszczególnymi grupami roślin ozdobnych, mając na uwadze perspektywy dalszego rozwoju handlu zagranicznego UE. Prezentowane poniżej badania stanowią kontynuację i uszczegółowienie analiz prowadzonych dotychczas $\mathrm{w}$ tym zakresie.

\section{Metodyka badań}

W analizach wykorzystano dane wtórne z międzynarodowych roczników AIPH (Association Internationale des Producterus de L'Horticulture).

Badano poziom i dynamikę zmian handlu zagranicznego i salda wymiany roślinami ozdobnymi Unii Europejskiej w ujęciu wartościowym w 1999 i 2014 roku. Przesłankami wyboru do badań powyższych lat był systematyczny wzrost nowych członków w strukturach UE, co mogło rzutować na obroty w handlu roślinami ozdobnymi. W 1999 r. analizy dotyczył 15 krajów, a w 2014 - 28 członków UE. W okresie tym następował systematyczny wzrost produkcji roślin ozdobnych w różnych rejonach świata, co mogło również wpływać na zmiany handlu roślinami ozdobnymi w UE.

Analizami objęto eksport i import roślin ozdobnych ogółem oraz siedmiu rodzajów produktów kwiaciarskich, tj. cebul kwiatowych, kwiatów ciętych świeżych, kwiatów ciętych preparowanych, zieleni ciętej świeżej i preparowanej, sadzonek, ozdobnych roślin 
szkółkarskich i roślin doniczkowych. Badano strukturę geograficzną handlu zagranicznego, uwzględniając wymianę wewnątrzunijna, a także handel Unii Europejskiej z krajami europejskimi spoza struktur, Afryką, Bliskim Wschodem, Ameryką Płn., Ameryką Łacińska, pozostałymi regionami na świecie, określonymi jako „inne”. Dla wszystkich grup produktów oraz roślin ogółem wyodrębniono pięciu największych dostawców i odbiorców w UE. Pozostałe państwa unijne ujęto w grupę ,inne”, w tym wyodrębniając Polskę.

W analizie zmian wartości importu i eksportu materiału szkółkarskiego, jako jego łączną wielkość przyjęto sumę drzew i krzewów ozdobnych oraz krzewów róż, natomiast w przypadku roślin doniczkowych azalii, doniczkowych ozdobnych z liści i kwiatów, a nie wielkości łączne $\mathrm{z}$ roczników AIPH. W związku $\mathrm{z}$ tym dane dotyczące handlu zagranicznego produktami kwiaciarskimi ogółem nie są równe sumie analizowanych grup produktów kwiaciarskich. Ze względu na brak porównywalności danych źródłowych podawanych w mierniku naturalnym, analiza handlu zagranicznego w ujęciu ilościowym nie była możliwa. W analizie zmian wartości eksportu i importu roślin ozdobnych w układzie czasowym posłużono się indeksami o podstawie stałej, przyjmując za podstawę 1999 rok. W analizie struktury geograficznej handlu, wykorzystano wskaźniki procentowe.

\section{Zmiany wartościowe eksportu i importu roślin ozdobnych w Unii Europejskiej}

W latach 1999-2014 w unijnym handlu zagranicznym roślinami ozdobnymi ogółem, nieco szybszą dynamikę wzrostu wykazywał eksport niż import. W badanym okresie eksport wzrósł o 72,3\% (tab. 1), czyli o 3966791 tys. euro, podczas gdy import o $65,9 \%$ (3490744 tys. euro). Konsekwencją tego było dodatnie saldo handlu zagranicznego UE, które w badanym okresie wzrosło ponad 3,5-krotnie.

Tabela 1. Wartość obrotów i saldo unijnej wymiany handlowej roślinami ozdobnymi w 1999 i 2014 roku

Table 1. The value of turnover and the balance of EU trade in ornamental plants in 1999 and 2014

\begin{tabular}{|c|c|c|c|c|c|c|c|c|}
\hline \multirow{3}{*}{$\begin{array}{c}\text { Grupy } \\
\text { produktów } \\
\text { kwiaciarskich }\end{array}$} & \multicolumn{6}{|c|}{ Wartość obrotów i saldo w tys. euro } & \multirow{2}{*}{\multicolumn{2}{|c|}{$\begin{array}{c}\text { Dynamika zmian } \\
1999=100\end{array}$}} \\
\hline & \multicolumn{3}{|c|}{1999} & \multicolumn{3}{|c|}{2014} & & \\
\hline & Eksport & Import & Saldo & Eksport & Import & Saldo & Eksport & Import \\
\hline Ogółem & 5490464 & 5293313 & +191157 & 9457255 & 8784057 & +673198 & 172,2 & 165,9 \\
\hline $\begin{array}{l}\text { Cebule } \\
\text { kwiatowe }\end{array}$ & 559281 & 313907 & +245374 & 777664 & 317699 & +459965 & 139,0 & 101,2 \\
\hline $\begin{array}{l}\text { Kwiaty cięte } \\
\text { świeże }\end{array}$ & 2165074 & 2427431 & -262357 & 3223277 & 3659266 & -435989 & 148,9 & 150,7 \\
\hline $\begin{array}{l}\text { Kwiaty cięte } \\
\text { preparowane }\end{array}$ & 52146 & 99498 & -47352 & 178959 & 217522 & -38563 & 343,2 & 218,6 \\
\hline Zieleń cięta & 309292 & 417370 & -108078 & 546108 & 577036 & -30928 & 176,6 & 138,3 \\
\hline Sadzonki & 238099 & 277309 & -39210 & 510070 & 543195 & -33125 & 214,2 & 195,9 \\
\hline $\begin{array}{l}\text { Rośliny } \\
\text { szkółkarskie }\end{array}$ & 356446 & 243582 & +112864 & 737802 & 467573 & +270229 & 207,0 & 192,0 \\
\hline $\begin{array}{l}\text { Kwiaty } \\
\text { doniczkowe }\end{array}$ & 1364956 & 1201665 & +163291 & 2304093 & 2166781 & +137312 & 168,8 & 180,3 \\
\hline
\end{tabular}

Źródło: opracowanie własne na podstawie AIPH, 2000 i 2015. 
Dodatnie saldo wymiany handlowej w 2014 roku UE osiągnęła w przypadku cebul kwiatowych, ozdobnych roślin szkółkarskich i kwiatów doniczkowych. O ile w przypadku cebul kwiatowych i roślin szkółkarskich, szybsza dynamika wzrostu wartości eksportu niż importu wpłynęła na wzrost dodatniego salda wymiany, tak w przypadku kwiatów doniczkowych szybszy wzrost importu spowodował obniżenie salda wymiany handlowej. W przypadku kwiatów ciętych, kwiatów ciętych preparowanych, zieleni ciętej i sadzonek, UE była importerem netto. Jednak w latach 1999-2014 ujemne saldo wymiany handlowej tymi produktów uległo obniżeniu. Sytuacja ta szczególnie widoczna jest w przypadku zieleni ciętej, bowiem wartość jej eksportu rosła szybciej niż importu, co spowodowało zmniejszenie ujemnego salda 3,5-krotnie. Wskazywać to może na wzrost produkcji sadzonek w UE, wzrost wolumenu eksportu, ale również wzrost cen materiału wyjściowego eksportowanego z UE. Jedynie w przypadku kwiatów ciętych odnotowano wzrost ujemnego salda wymiany handlowej, na skutek porównywalnej dynamiki wzrostu wartości eksportu i importu.

\section{Eksport produktów kwiaciarskich z Unii Europejskiej}

Z punktu widzenia producentów poszczególnych grup produktów kwiaciarskich istotna jest informacja o strukturze geograficznej handlu zagranicznego tymi produktami, a także zmiany wartości ich eksportu. W analizowanych latach głównymi odbiorcami unijnych produktów kwiaciarskich ogółem, jak i poszczególnych grup, były kraje członkowskie UE. Wewnątrzunijny eksport produktów kwiaciarskich ogółem w 2014 roku stanowił 79,8\% wartości całego eksportu z UE i w porównaniu do 1999 roku zmalał nieznacznie o 1,3 p.p. (tab. 2). Wartość eksportu wewnątrzunijnego w badanym 15-leciu wzrosła o 70,1\% (tab. 3), czyli o 3117894 tys. euro, na co tylko niewielki wpływ miała akcesja nowych członków. W latach 2003-2006, czyli w okresie przed i po poszerzeniu UE o nowych członków, wartość eksportu wewnątrzunijnego wzrosła jedynie o 8,6\%, jednak W wartościach absolutnych był to wzrost o 476377 tys. euro (Wróblewska, 2010). Wartość eksportu wewnątrzunijnego w 2014 roku była blisko 4-krotnie wyższa niż suma wartości eksportu w inne rejony świata. W strukturze unijnego eksportu wzrastał udział krajów Europy spoza jej struktur. Udział eksportu do tych krajów w całkowitym unijnym eksporcie produktami kwiaciarskimi w latach 1999-2014 wzrósł z 9,8 do 11,5\%, pomimo zmiany na przestrzeni lat, tj. zmniejszenia liczby krajów poza strukturami UE. W eksporcie roślinami ozdobnymi UE widać wyraźną regionalizację na obszarze Europy, natomiast inne kontynenty i rejony świata odgrywają mniejszą rolę, stanowiąc w 2014 roku jedynie 8,7\% wartości unijnego eksportu.

W 2014 roku udział eksportu wewnątrzunijnego w eksporcie ogółem poszczególnych produktów wahał się od 37,8 - w przypadku cebul kwiatowych, do 95,4\% w przypadku kwiatów ciętych preparowanych (tab. 2). Na przestrzeni analizowanych lat, jedynie w przypadku kwiatów ciętych preparowanych wzrósł nieznacznie udział krajów członkowskich jako ich odbiorców - o 9,5 p.p., a w przypadku sadzonek udział ten utrzymywał się na poziomie około $78 \%$. Wynikało to głównie z rozszerzenia liczby członków UE, które je importują, co jednocześnie znalazło odzwierciedlenie w spadku udziału krajów spoza struktur jako odbiorców wymienionych produktów. 
Tabela 2. Struktura geograficzna wartości eksportu produktów kwiaciarskich z Unii Europejskiej do poszczególnych regionów świata w 1999 i 2014 roku ( $\sum$ eksportu z UE = 100, \%)

Table 2. Geographical structure of the export value of floricultural products from the European Union to the various regions of the world in 1999 and 2014 ( $\sum$ export from $\left.\mathrm{EU}=100, \%\right)$

\begin{tabular}{l|ccccccccc}
\hline \multicolumn{1}{c}{$\begin{array}{c}\text { Grupy } \\
\text { produktów } \\
\text { kwiaciarskich }\end{array}$} & Lata & UE & $\begin{array}{c}\text { Europa } \\
\text { (bez UE) }\end{array}$ & Afryka & Azja & $\begin{array}{c}\text { Bliski } \\
\text { Wschód }\end{array}$ & $\begin{array}{c}\text { Ameryka } \\
\text { Północna }\end{array}$ & $\begin{array}{c}\text { Ameryka } \\
\text { Lacińska }\end{array}$ & Pozostałe \\
\hline Ogółem & 1999 & 81,1 & 9,8 & 0,4 & 3,1 & 0,8 & 4,2 & 0,5 & 0,1 \\
Cebule & 2014 & 79,8 & 11,5 & 0,4 & 3,1 & 1,4 & 2,4 & 0,8 & 0,5 \\
kwiatowe & 1999 & 48,8 & 7,2 & 0,6 & 18,5 & 0,6 & 19,4 & 1,7 & 3,3 \\
Kwiaty cięte & 2014 & 37,8 & 8,5 & 0,7 & 19,0 & 2,1 & 17,5 & 7,6 & 6,7 \\
Świeże & 1999 & 84,2 & 10,9 & 0,1 & 1,3 & 0,3 & 3,0 & 0,1 & 0,0 \\
Kwiaty cięte & 2014 & 81,7 & 13,8 & 0,1 & 1,4 & 0,8 & 1,9 & 0,1 & 0,3 \\
preparowane & 1999 & 81,7 & 7,1 & 0,7 & 2,0 & 2,0 & 6,2 & 0,2 & 3,0 \\
& 2014 & 95,4 & 1,8 & 0,5 & 0,4 & 0,3 & 1,3 & 0,1 & 0,7 \\
Zieleńn cięta & 1999 & 85,9 & 9,9 & 0,2 & 1,2 & 0,2 & 2,5 & 0,1 & 1,1 \\
& 2014 & 85,2 & 10,4 & 0,1 & 3,5 & 0,1 & 0,6 & 0,0 & 0,4 \\
Sadzonki & 1999 & 78,8 & 7,8 & 1,5 & 6,6 & 2,2 & 3,8 & 2,9 & 4,5 \\
& 2014 & 78,3 & 4,3 & 1,0 & 4,2 & 2,0 & 3,6 & 3,1 & 3,6 \\
Róliny & 1999 & 85,7 & 7,9 & 0,9 & 0,6 & 1,4 & 1,4 & 1,1 & 1,0 \\
szkółkarskie & 2014 & 76,6 & 13,4 & 0,4 & 3,7 & 4,3 & 0,1 & 0,0 & 1,4 \\
Kwiaty & 1999 & 85,9 & 10,3 & 0,4 & 0,6 & 0,7 & 0,5 & 0,1 & 1,5 \\
doniczkowe & 2014 & 84,5 & 12,4 & 0,1 & 0,5 & 1,2 & 0,1 & 0,1 & 1,0 \\
\hline
\end{tabular}

Źródło: opracowanie własne na podstawie AIPH, 2000 i 2015.

W analizowanych latach, zwiększenie wartości eksportu unijnego, miało miejsce głównie do krajów Europy niezrzeszonych w strukturach Unii. Udział tych krajów, jako odbiorców unijnych produktów kwiaciarskich wzrósł bowiem w przypadku wszystkich grup, poza wspomnianymi kwiatami preparowanymi i sadzonkami. Kraje spoza UE były odbiorcami przede wszystkim kwiatów ciętych, ozdobnych roślin szkółkarskich i zieleni ciętej, co stanowiło w 2014 roku odpowiednio 13,8;13,4 i 10,4\% unijnego eksportu.

Na przestrzeni analizowanych lat na stabilnym poziomie $(3,1 \%)$ kształtował się udział Azji jako odbiorcy produktów kwiaciarskich z UE (tab. 2). Ten relatywnie niewielki udział wynika z faktu, że Azja (głównie Chiny i Indie), jako największy producent kwiatów ciętych i doniczkowych na świecie, zaopatruje „lokalny rynek” azjatycki. Z UE na kontynent azjatycki eksportowane są głównie cebule kwiatowe, sadzonki i rośliny szkółkarskie, stanowiąc w 2014 roku odpowiednio 19,0; 4,2 i 3,7 \% wartości unijnego eksportu wymienionych grup produktów. W analizowanych latach odnotowano jednak wzrost wartości eksportu wszystkich grup produktów kwiaciarskich do Azji, za wyjątkiem kwiatów ciętych preparowanych, sadzonek i kwiatów doniczkowych. Najbardziej istotny wzrost wartości eksportu dotyczył natomiast roślin szkółkarskich. Na przestrzeni 15 lat wzrósł ponad 13-krotnie, stanowiąc w 2014 roku blisko 10\% wartości eksportu roślin ozdobnych ogółem na ten kontynent. 
Tabela 3. Dynamika zmian wartości eksportu produktów kwiaciarskich z Unii Europejskiej w poszczególne regiony świata w 2014 roku (indeks 1999=100)

Table 3. Dynamics of changes in the value of exports of floricultural products from the European Union to particular regions of the world in 2014 (index $1999=100)$

\begin{tabular}{|c|c|c|c|c|c|c|c|c|c|}
\hline & \multirow[b]{2}{*}{$\begin{array}{c}\text { Grupy } \\
\text { produktów } \\
\text { kwiaciarskich }\end{array}$} & \multicolumn{8}{|c|}{ Eksport do: } \\
\hline & & $\stackrel{5}{\supset}$ & 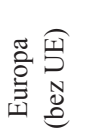 & $\sum_{\mathbb{E}}^{\stackrel{\pi}{4}}$ & $\frac{\pi}{\pi}$ & 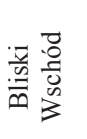 & 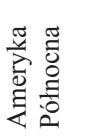 & 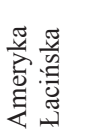 & $\begin{array}{l}\frac{0}{\pi} \\
\text { T⿱艹 } \\
0 \\
0 \\
0\end{array}$ \\
\hline \multirow{8}{*}{ 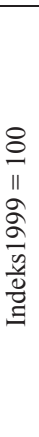 } & Ogółem & 170,1 & 202,6 & 157,5 & 171,2 & 314,0 & 100,3 & 299,5 & 620,4 \\
\hline & Cebule kwiatowe & 104,2 & 160,3 & 173,7 & 138,2 & 456,1 & 121,2 & 607,0 & 271,9 \\
\hline & $\begin{array}{l}\text { Kwiaty cięte } \\
\text { świeże }\end{array}$ & 144,6 & 187,6 & 108,8 & 155,5 & 347,2 & 95,4 & 80,3 & 3272,1 \\
\hline & $\begin{array}{l}\text { Kwiaty cięte } \\
\text { preparowane }\end{array}$ & 400,6 & 89,6 & 258,6 & 61,3 & 56,5 & 73,0 & 175,4 & 80,8 \\
\hline & Zieleń cięta & 175,0 & 185,9 & 77,4 & 525,0 & 125,4 & 42,7 & 71,2 & 70,9 \\
\hline & Sadzonki & 234,8 & 117,4 & 141,8 & 136,3 & 200,7 & 230,6 & 170,2 & 214,2 \\
\hline & $\begin{array}{l}\text { Rośliny } \\
\text { szkółkarskie }\end{array}$ & 185,9 & 350,5 & 100,5 & 1303,2 & 659,4 & 15,6 & 0,6 & 288,8 \\
\hline & $\begin{array}{l}\text { Kwiaty } \\
\text { doniczkowe }\end{array}$ & 165,1 & 201,0 & 61,4 & 154,5 & 283,9 & 48,6 & 91,9 & 113,8 \\
\hline
\end{tabular}

Źródło: opracowanie własne na podstawie AIPH, 2000 i 2015.

Zaobserwować można malejącą rolę Ameryki Północnej jako odbiorcy unijnych roślin ozdobnych, w tym wszystkich grup produktów kwiaciarskich. W latach 1999-2014 udział tego kontynentu jako importera roślin ozdobnych ogółem z UE obniżył się z 4,2 do 2,4\%, a w szczególności w zakresie importu materiału ozdobnego szkółkarskiego - z 5,2 do 0,1\%. Głównym eksportowym produktem kwiaciarskim z UE do Ameryki Północnej są cebule kwiatowe. W ostatnich latach stanowiły ponad $17 \%$ wartości unijnego eksportu tych produktów i ponad 57\% eksportu wszystkich produktów kwiaciarskich z UE do Ameryki.

Najmniejszy udział w wartości eksportu produktów kwiaciarskich z UE w 2014 roku miały Afryka $(0,4 \%)$, Ameryka Łacińska $(0,8 \%)$, Bliski Wschód $(1,4 \%)$ oraz regiony świata inne $(0,5 \%)$. Jednak udział ten systematycznie rośnie na skutek wzrostu wartości eksportu z UE. W latach 1999-2014 spośród wszystkich analizowanych regionów świata, wartość eksportu produktów kwiaciarskich ogółem z UE wzrosła najbardziej do tzw. regionów ,innych” - czyli do regionów spoza sklasyfikowanymi obszarami eksportu ujętymi w tab. 2 i 3., bo aż o 520,4\%. Jednak w wartościach absolutnych był to wzrost jedynie o 42568 tys. euro. Znaczny wzrost wartości eksportu odnotowano w eksporcie produktów kwiaciarskich na Bliski Wschód (214\%, czyli 89494 tys. euro) i do Ameryki Łacińskiej (199,5\%, 53207 tys. euro). Do Ameryki Łacińskiej eksportowane są głównie cebule kwiatowe, które stanowiły w 2014 roku 7,6\% wartości unijnego eksportu tych produktów i ponad 70\% wartości eksportu roślin ozdobnych ogółem do tego regionu świata. Na Bliski Wschód trafiało 4,3\% wartości unijnego eksportu roślin szkółkarskich, co stanowi około $25 \%$ wartości roślin ozdobnych ogółem importowanych z UE.

Najmniejszy i malejący poziom koncentracji unijnego handlu roślinami ozdobnymi na obszarze Europy miał miejsce w przypadku cebul kwiatowych, których światowym liderem w produkcji jest Holandia. W 1999 roku regiony spoza Europy importowały 51,2\% 
wartości unijnego materiału wyjściowego roślin cebulowych, w 2014 roku było to już $62,2 \%$. Odbiorcami cebul kwiatowych, o coraz większym znaczeniu, poza wspomnianymi regionami były także regiony ,inne” (6,7\% wartości unijnego eksportu cebul kwiatowych).

$\mathrm{Na}$ europejskim rynku kwiaciarskim największym odbiorcą roślin ozdobnych ogółem i analizowanych grup produktów kwiaciarskich w badanych latach były Niemcy. Jednak udział tego kraju jako odbiorcy unijnych roślin ozdobnych ogółem obniżył się z 39,4\% do $26,9 \%$, również w przypadku wszystkich, poza cebulami, grup produktów kwiaciarskich (tab. 4). Spadek tego udziału nastapił na skutek zmiany struktury samej UE, poprzez włączenie nowych członków, ale także wzrostu udziału Holandii, jako importera roślin ozdobnych z UE - w latach 1999-2014 z 5,7 do 9,7\%. W 2014 roku Holandia zajmowała czwartą pozycję pod względem wartości importu produktów kwiaciarskich z UE, a rosnąca jej rola jako importera dotyczyła głównie kwiatów ciętych i sadzonek.

Tabela. 4. Struktura geograficzna eksportu produktów kwiaciarskich z Unii Europejskiej do poszczególnych państw członkowskich w latach 1999 i 2014 (w ujęciu wartościowym, \%)

Table 4. The geographical structure of exports of European Union floriculture products to individual member states in 1999 and 2014 (by value, \%)

\begin{tabular}{|c|c|c|c|c|c|c|c|c|c|c|c|c|}
\hline \multirow[b]{2}{*}{$\begin{array}{c}\text { Grupy } \\
\text { produktów } \\
\text { kwiaciarskich }\end{array}$} & \multirow[b]{2}{*}{ Lata } & \multicolumn{11}{|c|}{ Eksport do: } \\
\hline & & 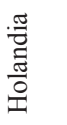 & $\frac{\vec{A}}{0}$ & 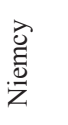 & 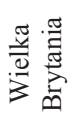 & 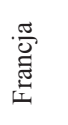 & 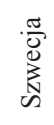 & $\frac{\cdot \frac{\pi}{00}}{\tilde{D}}$ & 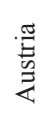 & 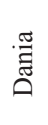 & $\stackrel{\mathscr{\Xi}}{\stackrel{\Xi}{\Xi}}$ & $\frac{\frac{\pi}{4}}{0}$ \\
\hline \multirow{2}{*}{ Ogółem } & 1999 & 5,7 & 6,1 & 39,4 & 13,5 & 16,6 & - & - & - & - & 18,7 & - \\
\hline & 2014 & 9,7 & 4,8 & 26,9 & 13,9 & 15,7 & - & - & - & - & 29,0 & 3,1 \\
\hline \multirow{2}{*}{$\begin{array}{l}\text { Cebule } \\
\text { kwiatowe }\end{array}$} & 1999 & 7,2 & 16,5 & 22,5 & 14,6 & 15,8 & - & - & - & - & 23,4 & - \\
\hline & 2014 & 5,8 & 7,2 & 23,8 & 18,4 & 10,9 & - & - & - & - & 33,9 & 5,2 \\
\hline \multirow{2}{*}{$\begin{array}{l}\text { Kwiaty cięte } \\
\text { świeże }\end{array}$} & 1999 & - & 5,2 & 41,0 & 16,9 & 17,1 & - & 3,6 & - & - & 16,2 & - \\
\hline & 2014 & 10,1 & 4,2 & 28,2 & 21,3 & 13,5 & - & - & - & - & 22,8 & 5,3 \\
\hline \multirow{2}{*}{$\begin{array}{l}\text { Kwiaty cięte } \\
\text { preparowane }\end{array}$} & 1999 & 7,4 & - & 44,5 & 5,4 & 18,2 & - & - & - & 0,7 & 23,8 & - \\
\hline & 2014 & 5,5 & - & 26,4 & 7,4 & 20,0 & - & - & - & 9,9 & 30,8 & 2,9 \\
\hline \multirow{2}{*}{ Zieleń cięta } & 1999 & 15,4 & 5,4 & 43,3 & 7,7 & 13,3 & - & - & - & - & 14,9 & - \\
\hline & 2014 & 19,1 & - & 31,8 & 10,4 & 11,1 & - & - & 3,7 & - & 23,9 & 2,9 \\
\hline \multirow{2}{*}{ Sadzonki } & 1999 & 14,7 & - & 28,1 & 13,0 & 12,0 & - & 5,7 & - & - & 26,5 & - \\
\hline & 2014 & 25,8 & - & 15,9 & 7,4 & 9,5 & - & 6,0 & - & - & 35,4 & 3,8 \\
\hline \multirow{2}{*}{$\begin{array}{l}\text { Rośliny } \\
\text { szkółkarskie }\end{array}$} & 1999 & 5,1 & - & 34,2 & 14,3 & 22,1 & - & 4,0 & - & - & 20,3 & - \\
\hline & 2014 & 9,2 & - & 18,7 & 14,2 & 21,1 & - & 5,7 & - & - & 31,2 & 3,8 \\
\hline \multirow{2}{*}{$\begin{array}{l}\text { Rośliny } \\
\text { doniczkowe }\end{array}$} & 1999 & - & 6,2 & 43,8 & 9,8 & 16,2 & 6,8 & - & - & - & 17,2 & - \\
\hline & 2014 & - & 6,4 & 31,2 & 7,1 & 18,3 & - & 5,9 & - & - & 31,0 & 3,1 \\
\hline
\end{tabular}

Dla poszczególnych grup produktów wyodrębniono 5 czołowych odbiorców, resztę krajów ujęto w grupę ,inne”

Źródło: opracowanie własne na podstawie AIPH, 2000 i 2015.

Do Francji, która zajmowała drugą pozycję, eksportowano około 1/5 wartości unijnych roślin szkółkarskich i kwiatów preparowanych. Wielka Brytania, jako trzeci 
importer roślin ozdobnych z UE, z udziałem 15\% w 2014 roku, była odbiorcą głównie kwiatów ciętych i cebul kwiatowych - odpowiednio 21,3 i 18,4\% unijnego eksportu tych produktów. Z kolei kraje „inne”, poza czołową piątką odbiorców z UE, importowały głównie sadzonki, cebule kwiatowe i kwiaty doniczkowe, które stanowiły odpowiednio 35,$5 ; 33,9$ oraz $31,0 \%$ wartości unijnego eksportu poszczególnych produktów. W strukturze unijnego eksportu, systematycznie wzrastało także znaczenie Polski, jako odbiorcy roślin ozdobnych. O ile w 2006 roku udział Polski jako odbiorcy roślin ozdobnych z Unii Europejskiej wynosił około 1,6\% (Wróblewska, 2010), to w 2014 roku wzrósł do poziomu $3,1 \%$ (tab. 4).

\section{Import produktów kwiaciarskich z Unii Europejskiej}

W strukturze geograficznej importu produktów kwiaciarskich do UE, dominuje import wewnątrzunijny, który w 1999 i 2014 roku utrzymał się na podobnym poziomie - ponad $80 \%$ wartości całego importu produktów kwiaciarskich do UE (tab. 5). Pomimo stabilnego udziału krajów unijnych jako dostawców roślin ozdobnych, jego wartość wzrosła o 67\% (tab. 6) o blisko 28798832 tys. euro. Było to głównie wynikiem wzrostu importu z krajów unijnych będących dotychczas największymi ich producentami, czyli tzw. „starych członków" oraz wzrostu liczy członków struktur unijnych na przestrzeni lat, które jednak wykazywały relatywnie niski poziom produkcji i eksportu produktów kwiaciarskich do UE (odpowiednio 0,8 i 0,2\% wartości unijnego importu). Wartość wewnątrzunijnego importu roślin ozdobnych ogółem w 1999 i 2004 roku była średnio 4,4-krotnie wyższa od wartości importu z wszystkich innych regionów świata. Udział poszczególnych produktów w imporcie wewnątrzunijnym w 2014 roku najwyższy był w przypadku roślin szkółkarskich (98,2\%), najniższy dla sadzonek i zieleni ciętej (odpowiednio 63,4 i 64,1\%).

Wzrasta rola Afryki, Azji innych regionów jako dostawców roślin ozdobnych do Europy, bowiem w 2014 roku udział wymienionych regionów w imporcie UE stanowił 10,6\% i w porównaniu z 1999 rokiem wzrósł o 3,9 p. p. Na przestrzeni analizowanych lat import z wymienionych regionów wzrósł odpowiednio o 180,9;100,1;328,0\%, choć w wartościach absolutnych był najwyższy w przypadku Afryki, tj. o 492991 tys. euro. Tym samym Afryka na przestrzeni analizowanych lat wysunęła się na drugą pozycję jako dostawca roślin ozdobnych do UE, spychając z tej pozycji Amerykę Łacińską. W Afryce, ze względu na korzystne warunki klimatyczne, tanią siłę roboczą oraz niskie koszty produkcji miał miejsce znaczny rozwój produkcji. W latach 1999-2014 areał upraw kwiatów ciętych i doniczkowych wzrósł do poziomu około 18.000 ha, czyli o blisko $430 \%$ (AIPH 2000, 2015). Do wzrostu tego przyczyniały się także inwestycje zagraniczne, w tym holenderskie (Jabłońska 2007). Holendrzy importują produkty kwiaciarskie wytworzone w Afryce, stając się, głównie w przypadku kwiatów ciętych, reeksporterem. Wzrost Afryki jako dostawcy roślin ozdobnych widoczny jest przede wszystkim w przypadku kwiatów ciętych oraz sadzonek - wartość ich importu wzrosła odpowiednio o 180,8\% i 330,8\%, stanowiąc w 2014 r. odpowiednio 17,5 i 16,5\% wartości unijnego importu wymienionych produktów. Trzecim pod względem wartości dostawca, z udziałem 5,3\% importu roślin ozdobnych na rynek unijny, była Ameryka Łacińska. Znaczenie tego rejonu jako dostawcy zmniejszyło się, szczególnie w przypadku zieleni ciętej i sadzonek, bowiem wartość importu w analizowanych latach obniżyła się o odpowiednio 29,4 i 37,2\%, stanowiąc w 2014 roku odpowiednio 12,2 i 5,5\% wartości importu tych produktów do UE. Ameryka 
Łacińska pozostaje jednak relatywnie dużym dostawcą kwiatów ciętych, z rosnącym na przestrzeni lat udziałem $8,3 \%$ wartości unijnego importu tej grupy produktów.

Tabela 5. Struktura geograficzna wartości importu produktów kwiaciarskich do Unii Europejskiej z poszczególnych regionów świata w 1999 i 2014 roku ( $\sum$ importu do $U E=100, \%$ )

Table 5. Geographical structure of the import value of floricultural products to the European Union from different regions of the world in 1999 and 2014 ( $\Sigma$ import to the $\mathrm{EU}=100, \%$ )

\begin{tabular}{|c|c|c|c|c|c|c|c|c|c|}
\hline \multirow{2}{*}{$\begin{array}{c}\text { Grupy } \\
\text { produktów } \\
\text { kwiaciarskich }\end{array}$} & \multirow[b]{2}{*}{ Lata } & \multicolumn{8}{|c|}{ Import z: } \\
\hline & & UE & $\begin{array}{c}\text { Europa } \\
\text { (bez UE) }\end{array}$ & Afryka & Azja & $\begin{array}{c}\text { Bliski } \\
\text { Wschód }\end{array}$ & $\begin{array}{l}\text { Ameryka } \\
\text { Północna }\end{array}$ & $\begin{array}{l}\text { Ameryka } \\
\text { Łacińska }\end{array}$ & Inne \\
\hline \multirow{2}{*}{ Ogółem } & 1999 & 81,4 & 0,8 & 5,2 & 1,4 & 3,0 & 1,8 & 6,3 & 0,1 \\
\hline & 2014 & 81,7 & 0,2 & 8,7 & 1,7 & 1,4 & 0,8 & 5,3 & 0,2 \\
\hline Cebule & 1999 & 92,0 & 1,6 & 0,7 & 1,0 & 1,7 & 0,8 & 2,0 & 0,2 \\
\hline Kwiatowe & 2014 & 88,3 & 2,6 & 0,8 & 1,6 & 1,9 & 1,4 & 3,0 & 0,4 \\
\hline Kwiaty & 1999 & 78,4 & 0,0 & 9,4 & 0,8 & 4,7 & 0,0 & 6,6 & 0,0 \\
\hline Cięte & 2014 & 71,9 & 0,0 & 17,5 & 0,5 & 1,7 & 0,0 & 8,3 & 0,0 \\
\hline \multirow{2}{*}{$\begin{array}{l}\text { Kwiaty cięte } \\
\text { preparowane }\end{array}$} & 1999 & 86,9 & 2,2 & 2,7 & 3,1 & 1,8 & 0,6 & 1,9 & 0,7 \\
\hline & 2014 & 85,6 & 0,0 & 4,2 & 1,3 & 0,2 & 0,0 & 8,6 & 0,2 \\
\hline Zieleń & 1999 & 39,3 & 2,3 & 3,1 & 4,6 & 3,6 & 20,7 & 23,9 & 2,5 \\
\hline Cięta & 2014 & 64,1 & 0,3 & 2,2 & 4,9 & 3,8 & 10,3 & 12,2 & 2,3 \\
\hline \multirow{2}{*}{ Sadzonki } & 1999 & 59,7 & 2,2 & 7,5 & 3,5 & 5,4 & 0,6 & 16,9 & 4,3 \\
\hline & 2014 & 63,4 & 0,4 & 16,5 & 5,0 & 5,6 & 0,2 & 5,5 & 3,4 \\
\hline \multirow{2}{*}{$\begin{array}{l}\text { Rośliny } \\
\text { Szkółkarskie }\end{array}$} & 1999 & 94,3 & 4,0 & 0,4 & 0,7 & 0,2 & 0,1 & 0,2 & 0,1 \\
\hline & 2014 & 98,2 & 0,6 & 0,3 & 0,4 & 0,2 & 0,1 & 0,1 & 0,1 \\
\hline \multirow{2}{*}{$\begin{array}{l}\text { Kwiaty } \\
\text { doniczkowe }\end{array}$} & 1999 & 96,1 & 0,2 & 0,3 & 1,2 & 0,2 & 0,2 & 1,3 & 0,6 \\
\hline & 2014 & 95,9 & 0,0 & 0,1 & 3,0 & 0,1 & 0,0 & 0,8 & 0,1 \\
\hline
\end{tabular}

Źródło: opracowanie własne na podstawie AIPH, 2000 i 2015.

Tabela. 6. Dynamika zmian wartości importu produktów kwiaciarskich do Unii Europejskiej z poszczególnych regionów świata w 1999 i 2014 roku (indeks $1999=100$ )

Table 6. Dynamics of changes in the value of import of floricultural products to the European Union from different regions of the world in 1999 and 2014 (index $1999=100$ )

\begin{tabular}{|c|c|c|c|c|c|c|c|c|c|}
\hline & \multirow[b]{2}{*}{$\begin{array}{c}\text { Grupy produktów } \\
\text { kwiaciarskich }\end{array}$} & \multicolumn{8}{|c|}{ Import z: } \\
\hline & & 岇 & 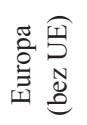 & $\stackrel{\frac{\pi}{2}}{E}$ & $\frac{\pi}{\frac{\pi}{4}}$ & 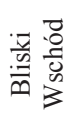 & 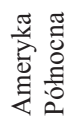 & 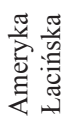 & $\stackrel{\Xi}{\Xi}$ \\
\hline \multirow{8}{*}{ 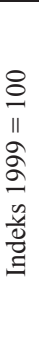 } & Ogółem & 167,0 & 32,5 & 280,9 & 200,1 & 81,1 & 69,8 & 139,0 & 428,0 \\
\hline & Cebule kwiatowe & 95,8 & 3,03 & 301,6 & 104,0 & 68,6 & 114,6 & 323,4 & 1017,8 \\
\hline & Kwiaty cięte & 138,4 & 93,5 & 280,8 & 97,1 & 55,8 & 11,9 & 189,6 & 840,5 \\
\hline & $\begin{array}{l}\text { Kwiaty cięte } \\
\text { preparowane }\end{array}$ & 216,7 & 0,18 & 338,8 & 92,8 & 20,9 & 4,2 & 966,9 & 64,0 \\
\hline & Zieleń cięta & 225,5 & 17,7 & 96,5 & 145,2 & 147,7 & 69,2 & 70,6 & 125,5 \\
\hline & Sadzonki & 206,3 & 36,0 & 430,8 & 278,5 & 204,5 & 56,9 & 62,8 & 155,9 \\
\hline & Rośliny szkółkarskie & 199,8 & 29,9 & 125,8 & 113,3 & 155,9 & 317,1 & 104,4 & 209,1 \\
\hline & Kwiaty doniczkowe & 179,2 & 11,6 & 23,3 & 433,7 & 73,1 & 18,6 & 111,8 & 29,4 \\
\hline
\end{tabular}

Źródło: opracowanie własne na podstawie AIPH, 2000 i 2015. 
Na przestrzeni lat zaobserwować można malejącą rolę Ameryki Północnej i Bliskiego Wschodu, jako dostawców roślin ozdobnych do UE. Wartość importu roślin ozdobnych z tych regionów zmalała o odpowiednio 30,2 i 18,9\%. Wartość importu z Ameryki Północnej obniżyła się w przypadku wszystkich, poza cebulami kwiatowymi i roślinami szkółkarskimi, grup produktów kwiaciarskich. Szczególnie zmalał udział Ameryki Północnej w unijnym imporcie zieleni ciętej tj. z 20,7 do 10,3\%. Z Bliskiego Wschodu na rynek unijny trafiały głównie sadzonki i zieleń cięta, choć z relatywnie niewielkim udziałem, w 2014 roku odpowiednio 5,6 i 3,8\% wartości unijnego importu.

Tabela. 7. Struktura geograficzna importu produktów kwiaciarskich do Unii Europejskiej z poszczególnych państw członkowskich w 1999 i 2014 roku (w ujęciu wartościowym, \%)

Table 7. The geographic structure of the import of floricultural products to the European Union from individual member states in 1999 and 2014 (by value, \%)

\begin{tabular}{|c|c|c|c|c|c|c|c|c|c|c|c|}
\hline \multirow[b]{2}{*}{$\begin{array}{r}\text { Grupy } \\
\text { produktów } \\
\text { kwiaciarskich }\end{array}$} & \multirow[b]{2}{*}{ Lata } & \multicolumn{10}{|c|}{ Import z: } \\
\hline & & 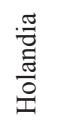 & $\begin{array}{l}\frac{\lambda}{0} \\
\frac{0}{3}\end{array}$ & $\begin{array}{l}\text { 己े } \\
\stackrel{\Xi}{\mathrm{Z}}\end{array}$ & 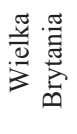 & 苞 & $\stackrel{\cdot \pi}{\Xi}$ & $\frac{.50}{000}$ & 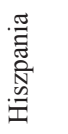 & $\underset{\Xi}{\stackrel{\Xi}{\Xi}}$ & $\frac{\frac{\pi}{4}}{0}$ \\
\hline \multirow{2}{*}{$\begin{array}{r}\text { Ozdobne } \\
\text { ogółem }\end{array}$} & 1999 & 74,4 & 5,1 & 3,2 & - & - & 5,8 & 5,7 & - & 5,8 & - \\
\hline & 2014 & 73,4 & 4,3 & 7,4 & - & - & 3,6 & 4,9 & - & 6,4 & 0,8 \\
\hline \multirow{2}{*}{$\begin{array}{r}\text { Cebule } \\
\text { kwiatowe }\end{array}$} & 1999 & 94,6 & - & 0,8 & 1,4 & 0,8 & - & 1,7 & - & 0,7 & - \\
\hline & 2014 & 88,6 & - & 5,8 & 1,0 & 0,8 & - & 1,0 & - & 2,8 & 0,1 \\
\hline \multirow{2}{*}{$\begin{array}{r}\text { Kwiaty cięte } \\
\text { świeże }\end{array}$} & 1999 & 89,4 & 2,2 & 1,0 & - & - & - & 1,6 & 4,1 & 1,7 & - \\
\hline & 2014 & 90,4 & 1,5 & 1,4 & - & - & - & 3,4 & 1,2 & 2,1 & 0,4 \\
\hline \multirow{2}{*}{$\begin{array}{l}\text { Kwiaty cięte } \\
\text { preparowane }\end{array}$} & 1999 & 82,0 & 4,6 & - & 3,1 & - & - & 2,2 & 2,2 & 5,9 & - \\
\hline & 2014 & 91,8 & 1,5 & 1,8 & 1,4 & - & - & - & 0,8 & 2,7 & 0,1 \\
\hline \multirow{2}{*}{ Zieleń cięta } & 1999 & 36,9 & 25,3 & 8,5 & - & - & 13,4 & 4,6 & - & 11,3 & - \\
\hline & 2014 & 39,9 & 8,5 & 9,0 & - & - & 18,9 & 7,2 & - & 16,5 & 4,0 \\
\hline \multirow{2}{*}{ Sadzonki } & 1999 & 53,7 & - & 7,7 & - & - & 7,0 & 9,3 & 11 , & 10,6 & - \\
\hline & 2014 & 45,6 & - & 29,6 & - & - & 3,3 & 5,0 & 3,8 & 12,7 & 2,3 \\
\hline \multirow{2}{*}{$\begin{array}{r}\text { Rośliny } \\
\text { szkółkarskie }\end{array}$} & 1999 & 55,6 & 17,5 & 5,9 & - & 4,4 & - & 9,2 & - & 7,4 & - \\
\hline & 2014 & 51,2 & 16,1 & 13,5 & - & - & - & 6,4 & 4,1 & 8,7 & 1,2 \\
\hline \multirow{2}{*}{$\begin{array}{r}\text { Rośliny } \\
\text { doniczkowe }\end{array}$} & 1999 & 60,2 & 4,6 & 4,2 & - & - & 16,5 & 12,1 & - & 2,4 & - \\
\hline & 2014 & 71,8 & 3,5 & 7,3 & - & - & 6,8 & 6,3 & - & 4,3 & 0,3 \\
\hline
\end{tabular}

Dla poszczególnych grup produktów wyodrębniono 5 czołowych odbiorców, resztę krajów ujęto w grupę ,inne”.

Źródło: opracowanie własne na podstawie AIPH, 2000 i 2015.

W latach 1999-2014 wzrost importu roślin ozdobnych do UE odnotowano z Azji, tj. o 100,1\%, czyli o około 76149 tys. euro, choć import z Azji stanowił w ostatnich latach niespełna 2\% unijnego importu. Na rynek unijny importowana była zieleń cięta i sadzonki. Kraje poza unijne, podobnie jak ,inne” regiony świata odgrywały w 2014 roku najmniejsze znaczenie w unijnym imporcie roślin ozdobnych, stanowiąc po $0,2 \%$ wartości tego importu, jednak ze wzrostową tendencją wartości importu z krajów „innych”, a malejącą z Europy. W latach 1999-2014, gros wewnątrzunijnego importu roślin ozdobnych pochodziła z Holandii - ponad 70\% (tab. 7), a wartość eksportu z tego kraju wzrosła o blisko 65\%. Kraj ten wśród wszystkich członków UE dostarczał na rynek ponad 90\% kwiatów ciętych 
świeżych i preparowanych, około 50\% materiału szkółkarskiego ozdobnego. Na przestrzeni lat udział Holandii w imporcie wewnątrzunijnym zmalał nieznacznie jedynie w przypadku cebul kwiatowych, materiału szkółkarskiego i sadzonek. Obecnie drugim największym eksporterem roślin ozdobnych do UE są Niemcy, z udziałem 7,4\% w imporcie wewnątrzunijnym i wzroście wartości eksportu o ponad $240 \%$. Rola Niemiec wzrosła szczególnie w przypadku dostaw sadzonek, roślin szkółkarskich i cebul kwiatowych - do poziomu odpowiednio 29,6 ; 13,5 i 5,8\% wartości unijnego importu tych produktów. Zbliżony udział w imporcie wewnątrzunijnym osiągnęły w 2014 roku Belgia $(4,9 \%)$, Włochy $(4,3 \%)$ i Dania $(3,6 \%)$, plasując się na kolejnych pozycjach $w$ rankingu największych dostawców roślin ozdobnych na rynek unijny. W eksporcie z Belgii na rynek unijny największą rolę odgrywała zieleń cięta, rośliny szkółkarskie i kwiaty doniczkowe, stanowiąc odpowiednio 9,3; 6,4 i 6,3\% wartości unijnego importu. Z kolei Dania znaczący udział miała w 2014 roku w eksporcie zieleni ciętej (18,9\% importu wewnątrzunijnego), choć jeszcze w 1999 roku, głównym dostawcą były Włochy zagospodarowując ponad 1/4 rynku unijnego tymi produktami. Włochy w eksporcie na rynek UE, spośród wszystkich produktów kwiaciarskich największy udział miały w przypadku roślin szkółkarskich, które stanowiły w 2014 roku 16,1\% wartości importu wewnątrzunijnego tymi produktami.

W strukturze unijnego importu, malał udział Polski, jako dostawcy roślin ozdobnych. W 2006 roku udział Polski w imporcie unijnym roślin ozdobnych ogółem wynosił około 1\% (Wróblewska, 2010), a w 2014 roku zmalał do poziomu 0,8\% (tab. 7).

\section{Podsumowanie}

Handel zagranicznym roślinami ozdobnymi UE charakteryzuje zasada bliskości geograficznej. Zarówno eksport, jak i import wewnątrzunijny stanowił około $80 \%$ całego eksportu i importu roślinami ozdobnymi UE. W latach 1999-2014 udział krajów członkowskich w unijnym eksporcie wzrósł o ponad 70\%, a w imporcie o $67 \%$. Głównym dostawcą roślin ozdobnych w UE była Holandia, z której sprowadzano blisko $75 \%$ wartości całego unijnego importu. Gros wszystkich grup produktów kwiaciarskich pochodziło z Holandii, co wynika $\mathrm{z}$ dominującej pozycji i specjalizacji tego kraju w produkcji i dystrybucji roślin ozdobnych. Natomiast głównym odbiorcą roślin ozdobnych z UE, ale o malejącym znaczeniu były Niemcy, z udziałem $27 \%$, przy rosnącym udziale eksportu do innych krajów unijnych. W handlu zagranicznym UE z innymi regionami świata wzrastała rola Afryki, jako dostawcy głównie kwiatów ciętych i sadzonek, malała rola Ameryki Północnej i Łacińskiej jako dostawców głównie zieleni ciętej. Natomiast w eksporcie produktów z UE na relatywnie stabilnym poziomie utrzymywał się udział Azji i Afryki jako odbiorców roślin ozdobnych z UE. Malało natomiast znaczenie Ameryki Północnej, która w 2014 roku nadal pozostawała jednak ważnym, podobnie jak Azja, odbiorcą cebul kwiatowych z blisko $20 \%$ udziałem w eksporcie z UE.

$\mathrm{Na}$ arenie światowej wymianę handlową produktami kwiaciarskimi Unii Europejskiej należy postrzegać w kontekście znaczenia samej Unii jako jednego z ważnych partnerów handlowych tymi produktami na arenie międzynarodowej oraz warunków gospodarowania zmieniających się na skutek procesów globalizacji. Aspektem przyczyniającym się do wzrostu handlu zagranicznego roślinami ozdobnymi UE są umowy o strefach wolnego handlu z państwami trzecimi, których celem jest zwiększenie możliwości eksportowych producentów unijnych. Mają one na celu zapewnienie korzystnych warunków dla 
sprzedaży towarów na rynkach poza unijnych. Pozycja Unii jako producenta roślin ozdobnych ma wpływ na współpracę międzynarodową i funkcjonowanie światowego rynku roślin ozdobnych. Układ sił pod względem produkcji roślin ozdobnych na świecie jest podzielony. Europa, w tym głównie UE, jako trzeci producent kwiatów na świecie, tworzy jeden z elementów „grupy strategicznej” na arenie międzynarodowej. W związku z tym układ ten, składający się z kilku centrów sprzyja regionalizacji handlu, co zaobserwowano w przeprowadzonych analizach na przykładzie UE. Koncentracja unijnego handlu roślinami ozdobnymi na obszarze Europy prowadzi do umacniania pozycji $\mathrm{w}$ skali regionalnej, tym samym zwiększając szanse w konkurencji globalnej.

\section{Literatura}

AIPH (2000, 2015). Hannover.

Goldfain, K. (2006). The African marketplace. Flora Culture International, listopad/grudzień, 28.

Gray, D.H. (2008). Kenya marches on. Flora Culture International, maj, 36-37.

Jabłońska, L. (1999). Zakres i zasady wspólnej organizacji rynku kwiaciarskiego w Unii Europejskiej (The scope and principles of the common organization of the floricultural market in the European Union). Biuletyn Agencji Rynku Rolnego 2, 16-28.

Jabłońska, L. (2007). Ekonomiczne aspekty rozwoju sektora kwiaciarskiego w Polsce (Economic aspects of the development of the floriculture sector in Poland). Wyd. SGGW, Warszawa.

Jabłońska, L. (2008). Pozycja Polski w świecie jako producenta roślin ozdobnych (Poland's position in the world as a producer of decorative plants). Roczniki Naukowe SERiA, 10(4), 124-129.

Jabłońska, L., Bońkowska, A., Oleśnicki, D., Stefanowska, A. (2013). Handel zagraniczny Unii Europejskiej roślinami ozdobnymi (Foreign trade of the European Union with ornamental plants). ZN SGGW Problemy Rolnictwa Światowego, 13(1), 37-48.

Jabłońska, L., Olewnicki, D., Kowalczyk, D. (2015). Zmiany w polskim handlu zagranicznym roślinami ozdobnymi w latach 2005-2012 (Changes in Polish foreign trade in decorative plants in the years 20052012). ZN SGGW Problemy Rolnictwa Światowego, 15(2), 65-74.

Marosz, A. Analiza wpływu zwiększającej się wymiany towarowej produktów roślin ozdobnych na rynkach światowych, przy bieżącym poziomie kosztów, na produkcję ogrodniczą w Polsce ze szczególnym uwzglednieniem rynku produktów szkółkarskich (Analysis of the impact of increasing trade in ornamental products on global markets, at the current cost level, for horticultural production in Poland, with particular emphasis on the market for nursery products). Analiza wykonana $\mathrm{w}$ ramach programu wieloletniego 2008-2014. Instytut Ogrodnictwa, Skierniewice. Pobrano 10 listopada 2017 z: http://www.inhort.pl.

Misala, J. (2011). Międzynarodowa konkurencyjność gospodarki narodowej (International competitiveness of the national economy). PWE, Warszawa.

Warunki prowadzenia handlu z zagranica w UE (Conditions for conducting trade with foreign countries in the EU). (2012). Enterprise Europe Network działający przy Polskiej Agencji Rozwoju Przedsiębiorczości. Warszawa, 2012. Pobrano 10 września 2017 z: www.parp.gov.pl oraz www.een.org.pl.

Wróblewska, W. (2010). Zmiany w unijnym handlu zagranicznym roślinami ozdobnymi wynikające z akcesji nowych członków (Changes in EU foreign trade in decorative plants resulting from the accession of new members). ZN SGGW Problemy Rolnictwa Światowego, 10(1), 116-124.

Do cytowania / For citation:

Wróblewska W., Kopiński Ł., Paszko D., Pawlak J. (2018). Unijny eksport i import roślin ozdobnych - zmiany w ujęciu rodzajowym i geograficznym. Problemy Rolnictwa Światowego, 18(1), 319-330; DOI: 10.22630/PRS.2018.18.1.29

Wróblewska W., Kopiński Ł., Paszko D., Pawlak J. (2018). EU Export and Import of Ornamental Plants - Changes in Generic and Geographical Approach (in Polish). Problems of World Agriculture, 18(1), 319-330; DOI: 10.22630/PRS.2018.18.1.29 